\title{
Bartholin Gland Adenoma
}

National Cancer Institute

\section{Source}

National Cancer Institute. Bartholin Gland Adenoma. NCI Thesaurus. Code C40299.

A rare, benign neoplasm that arises from the Bartholin gland and is characterized by the presence of clustered glands and tubules lined by mucin-secreting epithelial cells. 